\title{
SEASONAL VARIATION IN CHROMIUM HEXAVALENT AND COPPER CONTAMINATION IN GROUNDWATER OF JIMETA-YOLA AREA, NORTHEASTERN NIGERIA
}

J.M. ISHAKU AND H.I. EZEIGBO

(Received 26 March 2009; Revision Accepted 20, January 2010)

\begin{abstract}
Seasonal variation in heavy metal contamination of groundwater in the Jimeta- Yola area was investigated. The objectives of the study were to determine the seasonal variation in heavy metal contamination and to determine the influence of anthropogenic activities on heavy metal contamination. Groundwater samples were collected from hand-dug wells and boreholes between the dry season and rainy season periods. The water samples were analyzed using the DR/2010 spectrophotometer, TDS/conductivity meter and membrane filtration method. The results revealed that chromium hexavalent and copper enrichment occurred in the rainy season in the order $\mathrm{Cf}^{+6}<\mathrm{Cu}$. The source of these heavy metals contamination is anthropogenic. The mean values for chromium hexavalent and copper were 0.20 $\mathrm{mg} / \mathrm{l}$ and $0.69 \mathrm{mg} / \mathrm{l}$. The AF mean values for chromium hexavalent and copper were 20.1 and 70 while the $\mathrm{I}_{\text {geo }}$ mean values were -4.6 and -1.6 . The strong positive correlation between copper, AF and I $I_{\text {geo }}$ ranged from 0.74 to 0.99 while the correlation between $\mathrm{AF}$ and $\mathrm{I}_{\text {geo }}$ as it relates to copper was 0.43 . The strong positive correlation between chromium hexavalent, $\mathrm{AF}$ and $\mathrm{I}_{\text {geo }}$ ranged from 0.89 to 0.99 . The correlation between $\mathrm{AF}$ and $\mathrm{I}_{\text {geo }}$ as it relates to chromium hexavalent indicated a perfect correlation. These results indicated that anthropogenic input is the most likely source of these heavy metals and the contamination indices are weakly influenced by anthropogenic input in the case of copper and anthropogenic input is the only source influencing the contamination indices in the case of chromium hexavalent. Anthropogenic contamination was also indicated by the positive correlation between nitrate and $\mathrm{Ec}(\mathrm{r}=0.54), \mathrm{pH}$ and $\mathrm{Ec}(\mathrm{r}=0.36)$ and nitrate and $\mathrm{pH}(\mathrm{r}=0.34)$. Anthropogenic sources of contamination in the area include household solid waste, water pipes, and smelting works, wastes from mechanic workshop, metallurgical works, electrical machineries, electronic wastes, car scraps, computer inks, paints, chromium-plated plastics and sewage effluents. The groundwater quality is unfit for human consumption prior to treatment due to contamination by chromium hexavalent, nitrate and coliform bacteria.
\end{abstract}

KEY WORDS: Anthropogenic. Waste. Contamination. Groundwater. Heavy metals.

\section{INTRODUCTION}

Increasing interests in trace/heavy metals in the environments apparently is due to their toxicity and persistence within the drainage networks/aquatic systems (Salomon and Foester, 1984). Although sediments are said to represent the ultimate sinks for heavy metals in the environment (Gibbs, 1977), the environmental significance of the adsorbed concentrations lies in the relative ease of resolubilization into the water phase (Tijani et al., 2005). Surface and groundwater are increasingly subjected to a variety of heavy metal pollution attributed to urbanization, industrialization, and proliferation of chemical products, and even natural sources. Indiscriminate waste disposals generate leachates which contain a variety of heavy metals. Surface water quality may be affected if untreated leachate is discharged or due to leachate contaminated surface runoff into nearby water body (Christensen, 1992). Groundwater quality may be affected via infiltration of surface water through the aquifer systems, and groundwater-rock interaction. Urbanization, in proper land use pattern, and indiscriminate waste disposal can be a source of heavy metal pollution of groundwater (Tijani et al., 2004). The heavy metals of concern in the was as a result of the analyses carried out together with other heavy metals such as lead, lithium, cadmium, zinc and barium. The results revealed the presence of only chromium hexavalent and copper in both the dry season and rainy season periods in the area. Improper disposal of these metals in low-pH wastes gradually enhances their mobility (Minnesota Control Agency, 1999). According to Jenne (1968); Tijani et al (2005) that pH and Eh are the controlling factors of trace metals mobility in soils and groundwater. Trace metals may be absorbed or desorbed on soil particles depending on the $\mathrm{pH}$-Eh regime. According to Freeze and Cherry (1979), that the absorption capacity of these trace metals in groundwater may vary from one zone to another. They went further to state that man's activities may disturb the $\mathrm{pH}$-Eh regime, thus leading to the reduction in the absorption capacity or the reverse situation may occur. Copper may occur as $\mathrm{Cu}^{2+}$ or $\mathrm{Cu}^{1+}$ oxidation states and is derived from cuprite. High levels of copper in groundwater may come from fertilizer, septic systems, animal feedlots, industrial waste and food processing waste (Centre for Disease Control and Prevention, 2003). Low pH and soft water running through copper pipes and fittings can cause gradual leaching of copper resulting in elevated levels in drinking water (Sonon et

J.M. ISHAKU, Federal University of Technology, Yola, Nigeria

H.I. EZEIGBO Department of Geology, University of Nigeria, Nsukka, Nigeria 
iron ore, or chromite. It is widely distributed in soils and plants; it is rare in natural waters. Higher concentrations above the natural background value are indicators of anthropogenic pollution (Brilly et al., 2003). Chromium is found in two oxidation states as trivalent and hexavalent chromium. Chromium hexavalent exists as bichromate when the $\mathrm{pH}$ is below 6.5 and exists as chromate when the $\mathrm{pH}$ is above 6.5. Chromium hexavalent is mobile in the environment and is acutely toxic, $\mathrm{Cr}(\mathrm{III})$ has relatively low toxicity (Van Weerel, et al., 1984). Chromium has been released in to the environment due to poor waste disposal practice (Carl and Robert, 1984). Hence the objective of this work is to assess the contamination of chromium hexavalent and copper in groundwater system, and also assess the influence of anthropogenic activities on the heavy metal pollution in the study area.

\section{DESCRIPTION OF THE STUDY AREA}

The study area is situated between latitudes $9^{0} 11^{\prime} \mathrm{N}$ to $9^{0} 20^{\prime} \mathrm{N}$ and longitudes $12^{\circ} 23^{\prime} \mathrm{E}$ to $12^{\circ} 33^{\prime} \mathrm{E}$ covering an estimated area of $305 \mathrm{~km}^{2}$ (Fig. 1). The area has a mean annual rainfall of $918.9 \mathrm{~mm}$, and means monthly minimum temperature of $19^{\circ} \mathrm{C}$ and maximum temperature of $37.9^{\circ} \mathrm{C}$. The mean monthly temperature is $28.5^{\circ} \mathrm{C}$ (Ishaku, 2007). The mean monthly relative humidity in Yola varied from $26 \%$ in February to $76 \%$ in
August with mean relative humidity at $52.8 \%$ (Ishaku, 1995). The area is characterized by broadly flat to gentle undulations (Ishaku, 1995). The area is largely drained by the River Benue, which is characterized by extensive flood plains along which occur lakes Geriyo and Njuwa (Adekeye and Ishaku, 2004). Jimeta area is bordered by River Benue and lake Geriyo, and is dissected by a number of small streams (Ntekim and Bello, 2001), while Yola is bordered by lake Njuwa in the east. The major occupation of the people is agriculture while industries such as Nimafoam, Faro bottling Company and some other small-scale industries occur in the area. The population of the area is about 325,925 based on 2006 population census.

Water supply to the people is through surface water from water treatment plants while groundwater is obtained through b oreholes and hand-dug wells. The area lack a planned waste disposal system, waste disposal is through open dump for solid wastes as well as pit latrines and septic tank for human wastes (Yenika et al., 2003). The rate of waste generation per capita in Jimeta metropolis is about $0.90 \mathrm{~kg} / \mathrm{day}$, and is about $0.56 \mathrm{~kg} /$ day in Yola town (Tanko and Anametemfiok, 2001). Liquid wastes flow through drainage network and empty into the Benue River. The rural-urban migration into the state capital has caused rapid growth in population

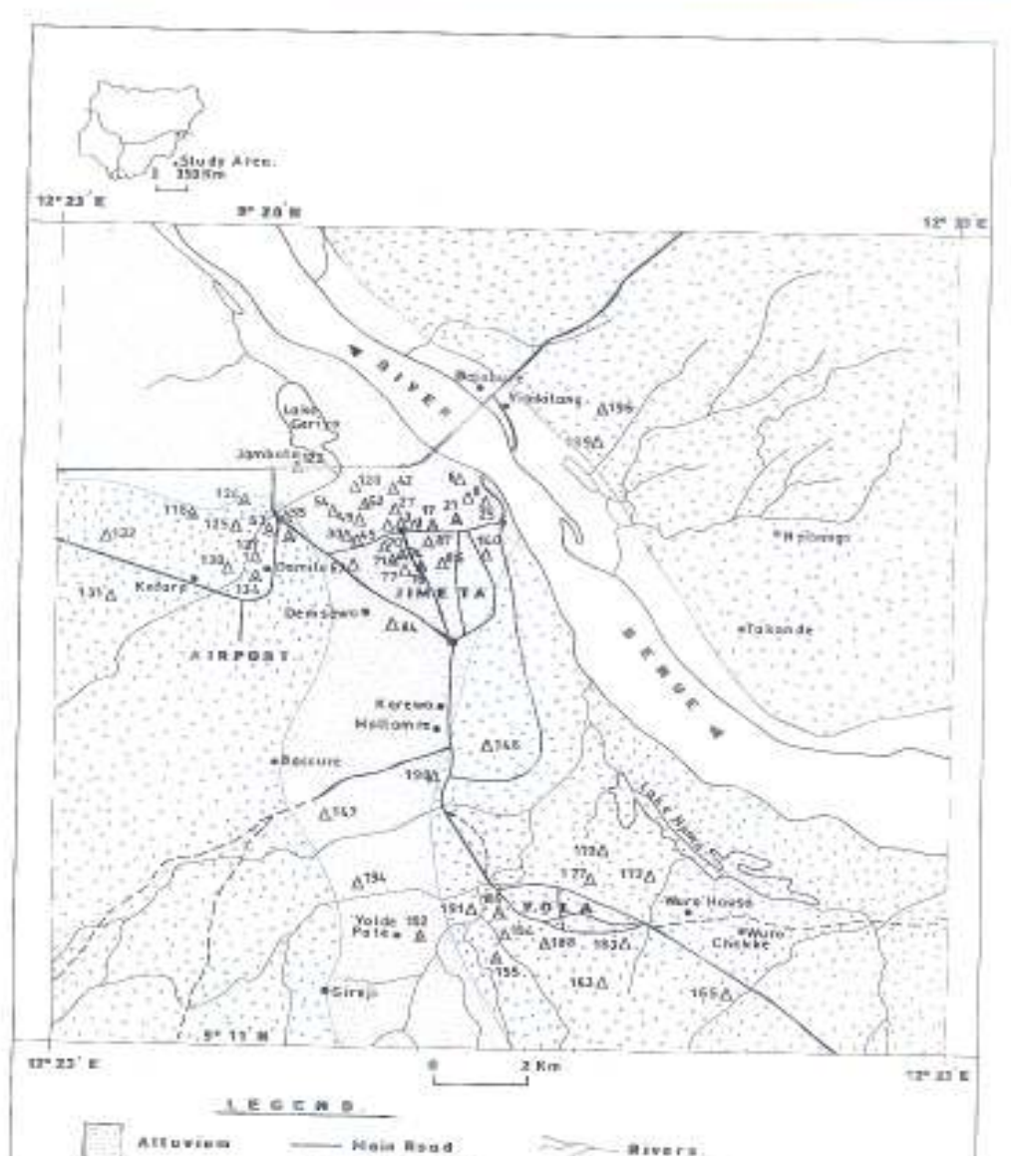


and unplanned expansion has made the urban infrastructure and services to lag behind population growth. The growth in population has affected the land use pattern, which has subsequently affected quality of the water resources (Adekeye and Ishaku, 2004). The study area is underlain by the Cretaceous Bima sandstone and Quaternary River Alluvium (Fig.1). The Bima sandstone is found at the base of the sedimentary succession and uncomformably overlies the Basement Complex (Offodile, 1989). The Bima sandstone consists of feldsparthic sandstone, grits, pebble beds, clays and shale (Offodile, 2002; Ishaku and Ezeigbo, 2000; Eduvie, 2000). The Bima sandstone underlies most parts of the study area. The River Alluvium consists of poorly sorted sands, clays, siltstones and pebbly sand (Ishaku and Ezeigbo; 2000, Yenika et al., 2003). The River Alluvium occurs along the flood plains and course of the main River Benue and extends to the southern part of the study area. Ishaku and Ezeigbo (2000) stated that the Bima sandstone in the Yola area is largely an unconfined aquifer while semi-confined conditions may be occurring in some places where aquitards occur. The saturated thickness of the aquifers varies from $32 \mathrm{~m}$ to $206 \mathrm{~m}$ with an average of $140.9 \mathrm{~m}$. The average hydraulic conductivity $(\mathrm{K})$ and transmissivity $(T)$ values for the aquifers are $1.63 \times 10^{-6} \mathrm{~m} / \mathrm{s}$ and $1.24 \times 10^{-2} \mathrm{~m}^{2} / \mathrm{s}$ respectively (Ishaku and Ezeigbo, 2000). Average borehole yields vary from $7.3 \mathrm{~m}^{3} / \mathrm{h}$ to $87.8 \mathrm{~m}^{3} / \mathrm{h}$ (Ishaku, 1995). The depths to water between the dry and rainy seasons in the area range from $0.82 \mathrm{~m}$ to $12.38 \mathrm{~m}$ in the hand-dug wells in the dry season and from $0.05 \mathrm{~m}$ to $11.85 \mathrm{~m}$ in the rainy season (Ishaku, 2007). In boreholes in the dry season, values range from $1.8 \mathrm{~m}$ to $40.53 \mathrm{~m}$ and from $1.1 \mathrm{~m}$ to $38.8 \mathrm{~m}$ in the rainy season. The depths of hand-dug wells range from $1.1 \mathrm{~m}$ to $12.5 \mathrm{~m}$, and total depths of boreholes range from $8 \mathrm{~m}$ to $170 \mathrm{~m}$ (Ishaku, 2007). Most boreholes range from $40 \mathrm{~m}$ to $45 \mathrm{~m}$ in total depths.

\section{METHODS OF INVESTIGATION}

Groundwater quality monitoring was carried out for the seasonal variations in the concentrations of copper and chromium hexavalent between the dry season and the rainy season periods. The monitoring started in March, 2005 and ended in September, 2005. Existing boreholes and hand-dug wells were used as the monitoring points (Fig.1). According to Chilton (1992), sampling of the discharge of existing boreholes is the most commonly used method for groundwater monitoring. Before the collection of the water samples, the plastic containers were rinsed twice with the samples to be collected according to Barcelona et al (1985) method. The analyses were carried out using DR/2010 spectrophotometer for chromium hexavalent, copper, nitrate and iron, while coliform bacteria were analyzed using membrane filtration method employing the use of membrane assemblage (Vacuum pump, Asbestos pad, Bukner flask and membrane funnel) and Leica Quebec Dark field colony counter. Electrical conductivity (Ec) and $\mathrm{pH}$ were determined in the field using TDS/conductivity meter (HACH KIT) and portable $\mathrm{pH}$ meter. Fifty-five (55) water samples were used for this study and the analyses were carried out at the
Adamawa State Water Board, Yola and the Department of Micro-biology, Federal University of Technology, Yola.

To establish the sources of the heavy metal contamination, indices such as anthropogenic factor $(A F)$ and index of geoaccumulation $\left(I_{\text {geo }}\right)$ were employed. Anthropogenic factor (AF) is a sort of quantification of the degree of contamination relative to composition of respective metal or to measured back ground vakues from geologically similar and uncontaminated area (Tijani et al., 2004). It is expressed as:

$\mathrm{AF}=\mathrm{Cm} / \mathrm{Bm}$

Where

$\mathrm{Cm}=$ measured concentration in sediment or water

$\mathrm{Bm}=$ back ground concentration (value) of metal either taken from literature (average shale/average crustal abundance) or directly determined from a geologically similar environment. In this study, the back ground values of the metals were taken as the concentration (values) of the metals in natural groundwater not affected by waste disposal. Base on this, the back ground value of chromium hexavalent in groundwater not affected by waste disposal is $0.01 \mathrm{mg} / \mathrm{l}$ (Hem, 1984). The back ground value for copper was taken from Davis and Dewiest (1966) as $0.01 \mathrm{mg} / \mathrm{l}$.

The index of geoaccumulation $\left(I_{\text {geo }}\right)$ was proposed by Mueller (1979) to also evaluate the degree of contamination. It is expressed as:

$$
\mathrm{I}_{\mathrm{geo}}=\log _{2}[(\mathrm{Cm}) /(1.5+\mathrm{Bm})]
$$

Where

$\mathrm{Cm}$ and $\mathrm{Bm}$ are as explained above, and 1.5 is a factor for possible variation in the back ground concentration due to lithologic difference. Mueller (1979) classified the index of geoaccumulation into; an index of geoaccumulation of $<0$ is practically uncontaminated; 0 1 is uncontaminated to slightly contaminated; 1-2 moderately contaminated; 2-3 moderately to highly contaminated; 3-4 highly contaminated and $>5$ very highly strongly contaminated.

RESULTS

The seasonal variations of heavy metals are presented in Tables 1 and 2 while the results of the physicchemical parameters are presented in Table 3. The summary of the results of the heavy metals and physic-

\section{6}

Table 4 , the $\mathrm{pH}$ of the water samples ranged from 5.98.5 in the dry season and ranged from 5.4-8.3 in the rainy season with mean values 7.0 and 6.9 for both the seasons. Ec values ranged from $60-4310 \mu S / \mathrm{cm}$ in the dry season and varied from $80-3500 \mu \mathrm{S} / \mathrm{cm}$ in the rainy season with mean values of $740 \mu \mathrm{S} / \mathrm{cm}$ and $732.2 \mu \mathrm{S} / \mathrm{cm}$ respectively. The results of heavy metals indicated that $\mathrm{Cr}^{+6}$ ranged from $0.01-0.11 \mathrm{mg} / \mathrm{l}$ in the dry season with an average of $0.02 \mathrm{mg} / \mathrm{l}$ while in the rainy season, values ranged from0.01-1.18 $\mathrm{mg} / \mathrm{l}$ with an average of $0.20 \mathrm{mg} / \mathrm{l}$. Copper concentrations varied from 0.01-2.16 $\mathrm{mg} / \mathrm{l}$ with a mean value of $0.43 \mathrm{mg} / \mathrm{l}$ in the dry season while in the rainy season, values ranged from 0.01-3.0 $\mathrm{mg} / \mathrm{l}$ with an average of $0.69 \mathrm{mg} / \mathrm{l}$. The concentrations of iron and nitrate varied from 0.01-5.6 $\mathrm{mg} / \mathrm{l}$ and 3.1-238.8 $\mathrm{mg} / \mathrm{l}$ in the dry season with mean values of 0.31 and $59.3 \mathrm{mg} / \mathrm{l}$. In the rainy season, their values ranged from 0.01-1.23 $\mathrm{mg} / \mathrm{l}$ and 4.9-224.1 $\mathrm{mg} / \mathrm{l}$ with mean values of 
$0.29 \mathrm{mg} / \mathrm{l}$ and $59.7 \mathrm{mg} / \mathrm{l}$. The coliform number counts ranged from nil to 75 in the dry season and ranged from nil to 50 in the rainy season with mean values of 19 and computed values of the anthropogenic factor (AF) as it relates to the concentrations of copper varied from 0.0 to
12 respectively. The indices used for the evaluation of heavy metal concentration in Tables 1 and 2 revealed that the

(Table 1). The computed values representing the index of geoaccumulation $\left(\mathrm{I}_{\text {geo }}\right)$ for copper concentration

154

ND $\quad 32.0 \quad-\quad-2.2 \quad-$

216 in the dry season and 1.0 to 300 in the rainy season

values varied from -7.2 to 0.5 in the dry season

Table 1 Values of copper in the Dry and Rainy season in the study area

$\mathrm{Hw}=\mathrm{Hand}-\mathrm{dug}$ well, $\mathrm{AF}=$ Anthropogenic factor, $\mathrm{I}_{\text {geo }}=$ Index of geoaccumulation, $\mathrm{BH}=$ Borehole, Bdl= below detection

\begin{tabular}{|c|c|c|c|c|c|c|c|c|c|c|c|c|c|c|c|}
\hline $\begin{array}{l}\text { Proj. } \\
\text { N0. } \\
(\mathrm{BH})\end{array}$ & $\begin{array}{l}\text { Copper } \\
\text { Dry } \\
\text { Season } \\
\mathrm{Mg} / \mathrm{l}\end{array}$ & $\begin{array}{l}\text { Copper } \\
\text { Rainy } \\
\text { Season } \\
\mathrm{Mg} / \mathrm{l}\end{array}$ & $\begin{array}{l}\text { AF } \\
\text { Dry } \\
\text { season }\end{array}$ & $\begin{array}{l}\text { AF } \\
\text { Rainy } \\
\text { season }\end{array}$ & $\begin{array}{l}I_{\text {geo }} \\
\text { Dry } \\
\text { season }\end{array}$ & $\begin{array}{l}\mathrm{I}_{\text {geo }} \\
\text { Rainy } \\
\text { season }\end{array}$ & $\begin{array}{l}\text { Proj. } \\
\text { N0. } \\
\text { (Hw) }\end{array}$ & $\begin{array}{l}\text { Copper } \\
\text { Dry } \\
\text { Season } \\
\mathrm{Mg} / \mathrm{l}\end{array}$ & $\begin{array}{l}\text { Copper } \\
\text { Rainy } \\
\text { Season } \\
\mathrm{Mg} / \mathrm{l}\end{array}$ & $\begin{array}{l}\text { AF } \\
\text { Dry } \\
\text { season }\end{array}$ & $\begin{array}{l}\mathrm{AF} \\
\text { Rainy } \\
\text { season }\end{array}$ & $\begin{array}{l}\mathrm{I}_{\text {geo }} \\
\text { Dry } \\
\text { season }\end{array}$ & $\begin{array}{l}\mathrm{I}_{\text {geo }} \\
\text { Rainy } \\
\text { season }\end{array}$ & $\begin{array}{l}\mathrm{pH} \\
\text { Dry } \\
\text { season }\end{array}$ & $\begin{array}{l}\mathrm{pH} \\
\text { Rainy } \\
\text { season }\end{array}$ \\
\hline 1 & Bdl & 0.53 & 0.0 & 53.0 & 0 & -1.5 & 73 & Bdl & 2.57 & 0.0 & 257.0 & 0.0 & 0.8 & 7.4 & 7.7 \\
\hline 2 & 0.09 & 0.36 & 9.0 & 36.0 & -4.0 & -1.2 & 74 & 0.40 & 1.55 & 40.0 & 155.0 & -1.9 & 0.04 & 8.0 & 7.7 \\
\hline 87 & 1.04 & 0.49 & 164.0 & 49.0 & 0.1 & -1.6 & 71 & 0.14 & 0.22 & 14.0 & 22.0 & -3.4 & -2.8 & 7.5 & 7.6 \\
\hline 194 & 0.17 & 0.05 & 17.0 & 5.0 & -3.2 & -4.9 & 17 & 0.03 & 1.06 & 3.0 & 106.0 & -5.7 & -0.5 & 7.6 & 7.1 \\
\hline 77 & Bdl & 0.68 & 0.0 & 68.0 & 0.0 & -1.2 & 27 & 1.30 & 1.75 & 130.0 & 175.0 & -0.2 & 0.2 & 7.4 & 7.6 \\
\hline 86 & 0.16 & 0.29 & 16.0 & 29.0 & -3.2 & -2.4 & 42 & Bdl & 1.37 & 0.0 & 137.0 & 0 & -0.1 & 8.5 & 7.8 \\
\hline 3 & 0.11 & 0.50 & 11.0 & 50.0 & -3.8 & -1.6 & 45 & 1.82 & 1.22 & 182.0 & 122.0 & 0.3 & -0.3 & 7.8 & 7.5 \\
\hline 6 & 0.05 & 2.25 & 5.0 & 225.0 & -4.9 & 0.6 & 54 & Bdl & 1.06 & 0.0 & 106.0 & 0 & -0.5 & 8.3 & 7.3 \\
\hline 8 & $\mathrm{Bdl}$ & 0.23 & 0.0 & 23.0 & 0.0 & -2.7 & 60 & 0.18 & ND & 18.0 & - & -1.3 & - & ND & ND \\
\hline 25 & 0.06 & 0.33 & 6.0 & 33.0 & -4.7 & -2.2 & 59 & 1.22 & 0.52 & 122.0 & 52.0 & -3.0 & -1.5 & 7.7 & 7.4 \\
\hline 49 & 0.33 & 0.28 & 33.0 & 28.0 & -2.2 & -2.4 & 124 & Bdl & 3.0 & 0.0 & 300.0 & 0 & 1.0 & 7.8 & 7.7 \\
\hline 52 & 0.13 & 0.19 & 13.0 & 19.0 & -1.3 & -3.0 & 116 & 0.06 & 1.11 & 6.0 & 111.0 & -4.7 & -0.4 & 7.6 & 8.2 \\
\hline 50 & 0.04 & 0.28 & 4.0 & 28.0 & -5.2 & -2.4 & 196 & 0.04 & 0.96 & 4.0 & 96.0 & -5.3 & -0.7 & 5.9 & 7.1 \\
\hline 67 & Bdl & 2.32 & 0.0 & 232.0 & 0.0 & 0.6 & 192 & 0.13 & 0.27 & 13.0 & 27.0 & -3.5 & -2.5 & 6.3 & 7.1 \\
\hline 120 & 0.14 & 0.2 & 0.0 & 2.0 & 0.0 & -2.9 & 155 & 0.08 & 0.16 & 8.0 & 16.0 & -4.2 & -3.2 & 6.7 & 7.5 \\
\hline 55 & 0.08 & 0.29 & 14.0 & 29.0 & -3.4 & -2.4 & 176 & 1.61 & 1.10 & 161.0 & 110.0 & 0.1 & -0.5 & 6.5 & 6.5 \\
\hline 125 & 0.10 & 0.47 & 8.0 & 47.0 & -4.3 & -1.7 & 184 & 0.67 & 0.54 & 67.0 & 54.0 & -1.2 & -1.5 & 8.0 & 5.4 \\
\hline 122 & Bdl & ND & 10.0 & - & -3.9 & - & 163 & 0.35 & 0.90 & 35.0 & 90.0 & -1.2 & -0.7 & 7.7 & 7.6 \\
\hline 108 & Bdl & 0.22 & 0.0 & 22.0 & 0.0 & -2.8 & 160 & 0.12 & 0.01 & 12.0 & 1.0 & -3.7 & -7.2 & 6.3 & 7.1 \\
\hline 130 & 0.32 & 0.22 & 0.0 & 22.0 & 0.0 & -2.8 & 188 & 1.33 & 0.81 & 133.0 & 81.0 & -0.2 & -0.9 & 7.9 & 7.5 \\
\hline 131 & 2.16 & 0.38 & 32.0 & 38.0 & -2.2 & 2.0 & 189 & 1.63 & 0.69 & 163.0 & 69.0 & 0.1 & -1.1 & 7.8 & 7.1 \\
\hline 132 & 0.22 & 0.20 & 216.0 & 20.0 & 0.5 & -2.9 & 173 & 0.01 & 0.53 & 1.0 & 53.0 & -7.2 & -1.5 & 6.7 & 6.5 \\
\hline 199 & 0.24 & 0.17 & 22.0 & 71.0 & -2.8 & -1.1 & 134 & 0.27 & 0.18 & 27.0 & 18.0 & -2.5 & -3.1 & 7.9 & 8.3 \\
\hline 172 & 0.21 & 0.51 & 24.0 & 51.0 & -2.7 & -1.6 & & & & & & & & & \\
\hline 140 & 0.06 & 0.33 & 21.0 & 33.0 & -2.8 & -2.2 & & & & & & & & & \\
\hline 146 & 0.24 & 0.27 & 6.0 & 27.0 & -4.7 & -2.5 & & & & & & & & & \\
\hline 190 & 0.19 & 0.23 & 24.0 & 23.0 & -2.7 & -2.7 & & & & & & & & & \\
\hline 147 & 0.09 & 0.57 & 19.0 & 57.0 & -3.0 & -1.4 & & & & & & & & & \\
\hline 191 & 0.32 & 0.16 & 9.0 & 16.0 & -4.1 & -3.2 & & & & & & & & & \\
\hline 154 & & ND & 32.0 & - & -2.2 & - & & & & & & & & & \\
\hline
\end{tabular}

limit,

$\mathrm{ND}=$ Not determined 
SEASONAL VARIATION IN CHROMIUM HEXAVALENT AND COPPER IN GROUNDWATER

Table 2 Values of chromium hexavalent in the Dry and Rainy season in the study area

\begin{tabular}{|c|c|c|c|c|c|c|c|c|c|c|c|c|c|c|c|}
\hline $\begin{array}{l}\text { Proj. } \\
\text { N0(BH) }\end{array}$ & $\begin{array}{l}\text { pH } \\
\text { Dry } \\
\text { season }\end{array}$ & $\begin{array}{l}\mathrm{pH} \\
\text { Rainy } \\
\text { season }\end{array}$ & $\begin{array}{l}\mathrm{Cr}^{+6} \\
\text { Dry } \\
\text { Season } \\
\mathrm{Mg} / 1\end{array}$ & $\begin{array}{l}\mathrm{Cr}^{+6} \\
\text { Rainy } \\
\text { season }\end{array}$ & $\begin{array}{l}\text { Dry } \\
\text { Season } \\
\text { AF }\end{array}$ & $\begin{array}{l}\text { Rainy } \\
\text { Season } \\
\text { AF }\end{array}$ & $\begin{array}{l}\text { Dry } \\
\text { Season } \\
\mathrm{I}_{\text {geo }}\end{array}$ & $\begin{array}{l}\text { Rainy } \\
\text { Season } \\
\mathrm{I}_{\text {geo }}\end{array}$ & $\begin{array}{l}\text { Proj. } \\
\text { N0(Hw) }\end{array}$ & $\begin{array}{l}\mathrm{Cr}^{+6} \\
\text { Dry } \\
\text { season }\end{array}$ & $\begin{array}{l}\mathrm{Cr}^{+6} \\
\text { Rainy } \\
\text { season }\end{array}$ & $\begin{array}{l}\text { Dry } \\
\text { Season } \\
\text { AF }\end{array}$ & $\begin{array}{l}\text { Rainy } \\
\text { Season } \\
\text { AF }\end{array}$ & $\begin{array}{l}\text { Dry } \\
\text { Season } \\
\mathrm{I}_{\text {geo }}\end{array}$ & $\begin{array}{l}\text { Rainy } \\
\text { Season } \\
\mathrm{I}_{\mathrm{geo}}\end{array}$ \\
\hline 1 & 6.4 & 6.2 & Bdl & 0.04 & 0.0 & 4.0 & 0 & -5.2 & 73 & Bdl & 0.12 & 0.0 & 12.0 & 0 & -3.7 \\
\hline 2 & 7.3 & 6.8 & 0.02 & 0.63 & 2.0 & 63.0 & -6.2 & -1.3 & 74 & 0.01 & 0.05 & 1.0 & 5.0 & -7.2 & -4.9 \\
\hline 87 & 8.0 & 8.0 & 0.02 & 0.04 & 2.0 & 4.0 & -6.2 & -5.2 & 71 & Bdl & 1.18 & 0.0 & 118.0 & 0 & -0.4 \\
\hline 77 & 6.5 & 6.4 & Bdl & 0.58 & 0.0 & 58.0 & 0 & -1.4 & 17 & Bdl & 0.53 & 0.0 & 53.0 & 0 & -1.5 \\
\hline 86 & 7.3 & 7.8 & Bdl & 0.06 & 0.0 & 6.0 & 0 & -4.7 & 27 & Bdl & 0.03 & 0.0 & 3.0 & 0 & -5.7 \\
\hline 3 & 6.4 & 6.1 & Bdl & 0.04 & 0.0 & 4.0 & 0 & -5.2 & 42 & Bdl & 0.07 & 0.0 & 7.0 & 0 & -4.4 \\
\hline 6 & 7.9 & 7.5 & 0.02 & 0.19 & 2.0 & 19.0 & -6.2 & -3.0 & 45 & 0.02 & 0.09 & 2.0 & 9.0 & -6.2 & -4.1 \\
\hline 8 & 6.9 & 6.4 & 0.01 & 0.05 & 1.0 & 5.0 & -7.2 & -4.9 & 54 & Bdl & 0.03 & 0.0 & 3.0 & 0 & -5.7 \\
\hline 25 & 6.7 & 6.4 & Bdl & 0.04 & 0.0 & 4.0 & 0 & -5.2 & 59 & 0.01 & 0.61 & 1.0 & 61.0 & -7.2 & -1.3 \\
\hline 49 & 6.6 & 6.1 & 0.05 & 0.05 & 5.0 & 5.0 & -4.9 & -4.9 & 124 & 0.01 & 0.12 & 1.0 & 12.0 & -7.2 & -3.7 \\
\hline 52 & 6.5 & 5.9 & 0.01 & 0.02 & 1.0 & 2.0 & -7.2 & -6.2 & 116 & 0.01 & 0.07 & 1.0 & 7.0 & -7.2 & -4.4 \\
\hline 50 & 6.5 & 6.0 & 0.01 & 1.10 & 1.0 & 110.0 & -7.2 & -0.5 & 196 & 0.02 & 0.08 & 2.0 & 8.0 & -6.2 & -4.2 \\
\hline 67 & 6.8 & 6.2 & Bdl & 0.65 & 0.0 & 65.0 & 0 & -1.2 & 192 & 0.01 & 0.01 & 1.0 & 1.0 & -7.2 & -7.2 \\
\hline 120 & 6.8 & 6.7 & 0.01 & 0.05 & 1.0 & 5.0 & -7.2 & -4.9 & 155 & 0.03 & 0.04 & 3.0 & 4.0 & -5.7 & -5.2 \\
\hline 55 & 6.9 & 6.6 & Bdl & 0.03 & 0.0 & 3.0 & 0 & -5.7 & 176 & 0.03 & 0.01 & 3.0 & 1.0 & -5.7 & -7.2 \\
\hline 125 & 7.7 & 7.0 & Bdl & 0.06 & 0.0 & 6.0 & 0 & -4.7 & 184 & 0.11 & 0.01 & 11.0 & 1.0 & -3.8 & -7.2 \\
\hline 108 & 6.7 & 6.0 & 0.01 & 0.06 & 1.0 & 6.0 & -7.2 & -4.7 & 163 & 0.02 & 0.01 & 2.0 & 1.0 & -6.2 & -7.2 \\
\hline 130 & 6.9 & 7.6 & 0.01 & 0.04 & 1.0 & 4.0 & -7.2 & -5.2 & 160 & 0.01 & 0.01 & 1.0 & 1.0 & -7.2 & -7.2 \\
\hline 131 & 6.6 & 6.7 & 0.03 & 0.05 & 3.0 & 5.0 & -5.7 & -4.9 & 188 & 0.01 & 0.02 & 1.0 & 2.0 & -7.2 & -6.2 \\
\hline 132 & 6.8 & 7.5 & 0.02 & 0.05 & 2.0 & 5.0 & -6.2 & -4.9 & 189 & 0.05 & 0.01 & 5.0 & 1.0 & -4.9 & -7.2 \\
\hline 199 & 6.6 & 6.8 & 0.03 & 0.03 & 3.0 & 3.0 & -5.7 & -5.7 & 173 & 0.06 & 0.01 & 6.0 & 1.0 & -4.7 & -7.2 \\
\hline 140 & 6.3 & 6.6 & 0.02 & 1.02 & 2.0 & 102.0 & -6.2 & -0.6 & 134 & 0.02 & 0.02 & 2.0 & 2.0 & -6.2 & -6.2 \\
\hline 146 & 7.0 & 6.6 & 0.01 & 1.12 & 1.0 & 112.0 & -7.2 & -0.4 & & & & & & & \\
\hline 190 & 7.7 & 7.9 & 0.01 & 0.63 & 1.0 & 63.0 & -7.2 & -1.3 & & & & & & & \\
\hline 147 & 7.3 & 7.2 & 0.02 & 0.55 & 2.0 & 55.0 & -6.2 & -1.5 & & & & & & & \\
\hline 191 & 6.2 & 5.7 & 0.01 & 0.01 & 1.0 & 1.0 & -7.2 & -7.2 & & & & & & & \\
\hline 165 & 7.0 & 7.7 & 0.03 & 0.02 & 3.0 & 2.0 & -5.7 & -6.2 & & & & & & & \\
\hline 194 & 6.0 & 6.4 & 0.01 & 0.01 & 1.0 & 1.0 & -7.2 & -7.2 & & & & & & & \\
\hline 183 & 6.2 & 6.1 & 0.02 & 0.02 & 2.0 & 2.0 & -6.2 & -6.2 & & & & & & & \\
\hline 177 & 6.0 & 5.5 & 0.02 & 0.02 & 2.0 & 2.0 & -6.2 & -6.2 & & & & & & & \\
\hline 172 & 6.1 & 6.8 & 0.06 & 0.01 & 6.0 & 1.0 & -4.7 & -7.2 & & & & & & & \\
\hline 178 & 6.4 & 6.6 & 0.04 & 0.01 & 4.0 & 1.0 & -5.2 & -7.2 & & & & & & & \\
\hline 70 & - & 6.6 & 0.03 & 0.62 & 3.0 & 62.0 & -5.7 & -1.3 & & & & & & & \\
\hline
\end{tabular}

$\mathrm{Hw}=\mathrm{Hand}$-dug wells, $\mathrm{AF}=$ Anthropogenic factor, $\mathrm{I}_{\mathrm{geo}}=$ Index of geoaccumulation, $\mathrm{BH}=$ Borehole $\mathrm{Bdl}=$ Below detection limit 


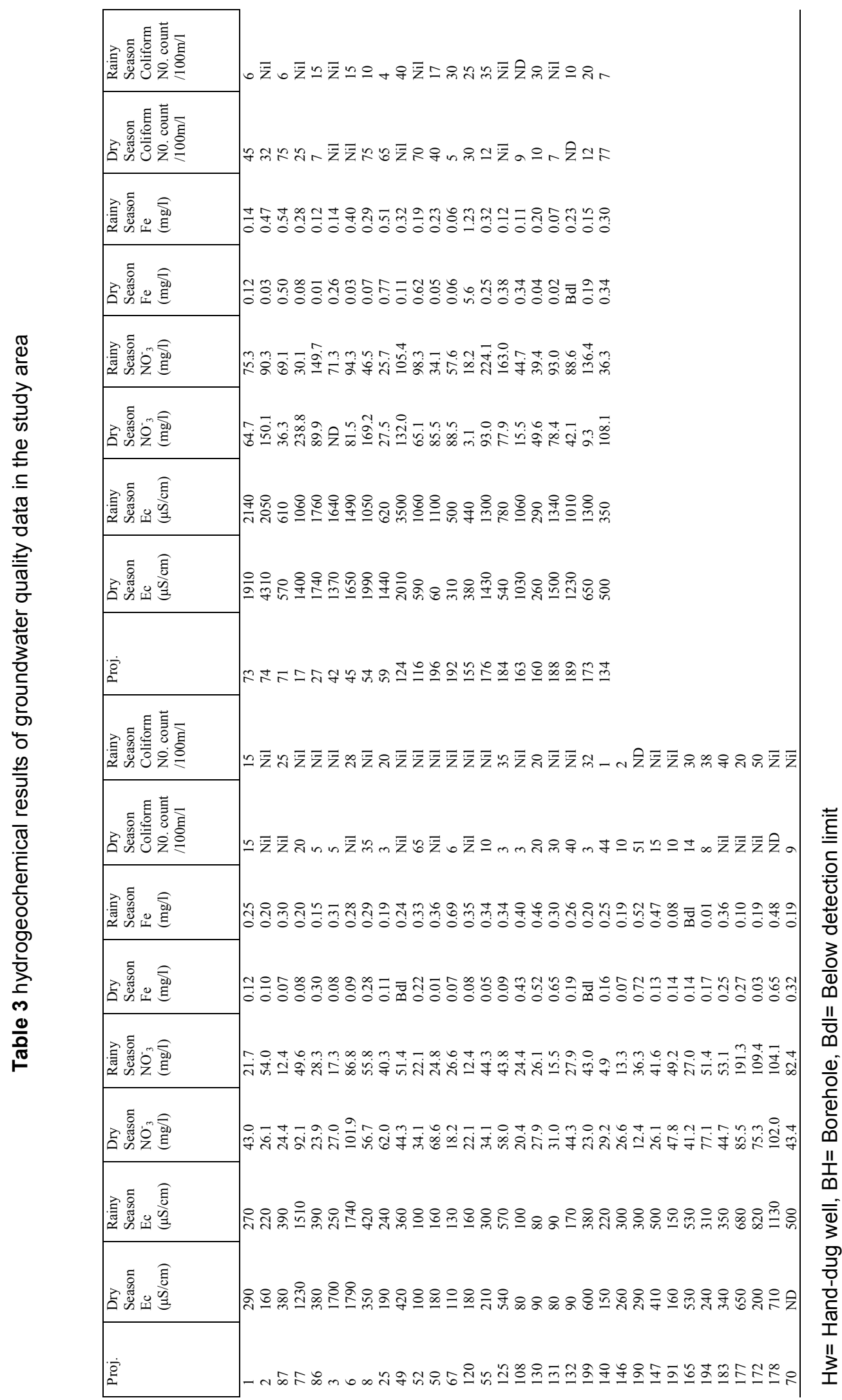


Table 4 Summary of heavy metals and physic-chemical parameters in the study area *USEPA (1975), **WHO (1984)

\begin{tabular}{|c|c|c|c|c|c|}
\hline \multirow{2}{*}{$\begin{array}{l}\text { Measured } \\
\text { Parameters }\end{array}$} & \multicolumn{2}{|l|}{ Range } & \multirow{2}{*}{$\begin{array}{l}\text { Dry season } \\
\text { Mean }\end{array}$} & \multirow{2}{*}{\begin{tabular}{ll} 
Rainy & \\
& \multicolumn{1}{l}{ seaso } \\
n & \\
mean &
\end{tabular}} & \multirow{2}{*}{$\begin{array}{l}\text { WHO } \\
\text { (1993) }\end{array}$} \\
\hline & Dry season & Rainy season & & & \\
\hline $\begin{array}{l}\text { Chromium } \\
\text { Hexavalent }(\mathrm{mg} / \mathrm{l})\end{array}$ & $0.01-0.11$ & $0.01-1.18$ & 0.02 & 0.20 & $0.05^{*}$ \\
\hline Copper(mg/l) & $0.01-2.16$ & $0.01-3.00$ & 0.43 & 0.69 & 1.0 \\
\hline $\operatorname{Iron}(\mathrm{mg} / \mathrm{l})$ & $0.01-5.60$ & $0.01-1.23$ & 0.31 & 0.29 & 0.3 \\
\hline Nitrate $(\mathrm{mg} / \mathrm{l})$ & $3.10-238.80$ & $4.9-224.1$ & 59.3 & 59.7 & 50 \\
\hline $\operatorname{Ec}(\mu \mathrm{S} / \mathrm{cm})$ & $\begin{aligned} 60.00- & \\
& 4310 . \\
& 00\end{aligned}$ & $80.0-3500$ & 740.0 & 732.2 & 1450 \\
\hline Coliform & Nil-75 & Nil-50 & 19 & 12 & $0-3 * *$ \\
\hline $\mathrm{pH}$ & $5.9-8.5$ & $5.4-8.3$ & 7.0 & 6.9 & $6.5-9$ \\
\hline
\end{tabular}

and values ranged from -7.2 to 2.0 in the rainy season. The AF for $\mathrm{Cr}^{+6}$ varied from 0.0 to 11.0 in the dry season and 1.0 to 118.0 in the rainy season (Table 2 ). The $\mathrm{I}_{\text {geo }}$ for $\mathrm{Cr}^{+6}$ varied from -7.2 to 0 in the dry season and -7.2 to -0.4 in the rainy season.

\section{DISCUSSION OF RESULTS}

From the mean results presented, the $\mathrm{pH}$ mean values is higher in the dry season, however, the difference between the mean values did not show much significance (mean values are 7.0 in the dry season and 6.9 in the rainy season). The $\mathrm{pH}$ values ranged from acidic to alkaline throughout the monitoring period. The Ec values revealed higher mean value in the dry season and lower in the rainy season. The higher mean value suggests higher anthropogenic pollution in the dry season which could be due to absence of dilution and higher rate of evaporation in the dry season. The mean values of $\mathrm{Ec}$ and $\mathrm{pH}$ are below $\mathrm{WHO}$ recommended limits in both the dry season and rainy season periods. The mean coliform number counts are higher in the dry season than the rainy season periods. The mean values for the dry and rainy season have exceeded the WHO recommended limit (Table 4). Chromium hexavalent and copper revealed higher mean values in the rainy season than the dry season period which could be attributed to the dissolution of waste materials and subsequent releasing of leachates coupled with the remobilization of the metals bounded to sediments into the groundwater. Thus, the mean concentrations of the heavy metals in terms of abundance is in the order of $\mathrm{Cr}^{+6}<\mathrm{Cu}$. The mean values of the heavy metals $\left(0.20 \mathrm{mg} / \mathrm{l} \mathrm{for} \mathrm{Cr}^{+6}\right.$ and $0.69 \mathrm{mg} / \mathrm{l}$ for copper) are above the natural background values of $0.01 \mathrm{mg} / \mathrm{l}$ which is an indication of contamination. The mean values of the heavy metals in dry season though lower than the rainy season; values still exceeded the back ground values, this is also an indication of contamination. The order of abundance of the heavy metals $\left(\mathrm{Cr}^{+6}<\mathrm{Cu}\right)$ could also be attributed to the differences in the mobility of the metals. The low concentrations of chromium hexavalent could be due to the reduction of chromium hexavalent to chromium trivalent. Carl and Robert (1994) stated that $\mathrm{Cr}(\mathrm{VI})$ is a electron donors. Electron donors commonly found in the soils include aqueous $\mathrm{Fe}$ (III), ferrous iron minerals; reduced sulphur and soil organic matter. Copper is also known to be mainly retained in soils through exchange and specific adsorption mechanism and has a high affinity for organic ligands and humic compounds

\section{0}

rainy season, the difference is however not significant. Nitrate mean values also did not show significant difference between the seasons, all the mean values however exceeded WHO recommended limit. The correlation of the physic-chemical parameters using the Pearson correlation revealed positive correlation between nitrate and $\mathrm{Ec}_{\mathrm{c}}(\mathrm{r}=0.54), \mathrm{pH}$ and $\mathrm{Ec}(\mathrm{r}=0.36)$ and nitrate and $\mathrm{pH}(\mathrm{r}=0.34)$. The positive correlation between the physical parameters and nitrate is an indication of a common source which is anthropogenic. Attempts to correlate the physic-chemical parameters and the heavy metals could not yield any form of correlation. This could be attributed to the differences in the chemical behaviors of the metals. Correlation of the mean values of the physic-chemical parameters revealed that $\mathrm{pH}$, Ec, iron and copper are below the maximum permissible limit of WHO (1993) standards for drinking water (Table 4). Although the mean copper concentration is below the WHO recommended limit, long term cumulative intake could posse threat to human health (Sonon et al., 2003). The mean value of copper observed to fall below WHO limit does not imply absence of contamination as lower concentrations could be attributed to adsorption on soil particles/sediments in the study area. From Table 1, Boreholes 6 and 67 and hand-dug wells 27, 45, 59, 176, 188 and 189 recorded higher concentrations of copper in the rainy season period. These boreholes and handdug wells are located opposite the banks of the Benue River (BH6) where most of the solid wastes are deposited; others are located in the densely populated areas of Demsawo area in Jimeta metropolis, opposite Jimeta main market and in the densely populated area of Lamido Sanda in Yola town. Chromium hexavalent revealed higher mean value in the rainy season which is above the USEPA (1975) standard limit of $0.05 \mathrm{mg} / \mathrm{l}$ for drinking water. This is an indication of serious threats 
due to chromium hexavalent in the area. The controlling factor for chromium hexavalent enrichment could be related to the $\mathrm{pH}$ of the different environments for both the hand-dug wells and boreholes in the area (Ishaku, 2007). The author went further to indicate that most samples from the hand-dug wells in both the dry and rainy seasons revealed mostly neutral $\mathrm{pH}$ conditions with few acidic and alkaline conditions. The borehole samples revealed mostly acidic $\mathrm{pH}$ conditions. Boreholes 50, 140 and 146 revealed higher concentrations in chromium hexavalent in the rainy season (Table 2). These boreholes are located down gradient of refuse dumps located in densely populated areas. The high level of chromium hexavalent in the rainy season in the area could be associated with waste materials, oxidation of $\mathrm{Cr}$ (III) to $\mathrm{Cr}(\mathrm{VI})$ and reduction of $\mathrm{Cr}$ (VI) by aqueous Fe (II) and soil organic matter. The sources of chromium hexavalent could be due to household solid wastes, and pigments resulting from the numerous small-scale industries involved in the dyeing of clothes, inks from computer cart ridges, dissolution of paints from buildings and chromium plated-plastics. Chromium compounds are used in metal cleaning; pre plating and electroplating, skin tannage, and in the manufacture of inks, paint pigments, chromium-plated plastics and dyes (Brilly et al., 2003; Shinya and Hiroyuki, 2005; US patent, 2005). High levels of chromium are known to cause skin lesions and gastrointestinal ulcers (Smith and Allean, 1975). High levels of chromium hexavalent is also known to be mutagenic (Bonatti et al., 1976; and Paschin et al., 1983), teratogenic (Abbasi and Soni (1984) and carcinogenic (Mancuso and Hueper, 1951; Mancuso, 1951; Waterhouse, 1975; Yassi and Nieboer, 1988; and One, 1988). Also, the high concentration of copper in the rainy season could be associated with acidic nature of the groundwater in the area. $\mathrm{pH}$ ranges from 5.4 to 8.3 in the rainy season. Low $\mathrm{pH}$ water influences the dissolution of copper from waste materials. Recharge water under acidic condition can increase the resolubility of copper and its eventual release into the groundwater. The atmospheric dissolution of carbon dioxide by precipitation and organic decomposition in the soil zone could be responsible for lowering of $\mathrm{pH}$ and thus enhancing the dissolution of copper by-product from wastes and copper bounded to sediments in the area. Sources of copper in the area include water pipes, smelting works, mechanics workshop, metallurgical works, electrical machineries, electronics, and car scraps. Health hazards due to drinking water with elevated concentration of copper include stomach and intestinal distress, liver and kidney damage, and anemia (Centre for Disease Control, 2003; Sonon et al., 2006). The higher concentrations of copper and chromium hexavalent in the rainy season could be anthropogenic resulting from the dissolution of waste materials. Anthropogenic pollution is confirmed by the higher values of nitrate and coliform bacteria in both the dry season and rainy season periods which are above the recommended limit of WHO (1993). Possible sources of nitrate and coliform bacteria in the area could be from household solid wastes and sewage effluents following the use of pit latrines by many residents. The heavy metal contamination in the study area was determined using anthropogenic factor (AF) and index of geoaccumulation $\left(\mathrm{I}_{\mathrm{geo}}\right)$. The back ground values of the heavy metals in natural groundwater not affected by contamination were employed in order to give a comparative idea about the quality and the degree of heavy metal contamination in the study area. Table 5 indicated that the anthropogenic factor (AF) for chromium hexavalent revealed higher mean value in the rainy season which implied high degree of contamination in the rainy season period due to high anthropogenic input. The mean AF value for copper was also high in the rainy season. This mean value also revealed that the degree of contamination is high in the rainy season, thus indicating high anthropogenic inputs. The AF value for copper ranged from 1.0 to 300.0 in the rainy season and that of chromium hexavalent ranged from 1.0 to 118.0 (Table 1 and 2). In the absence of any contamination above the back ground value, the AF values for the heavy metals is suppose to be unity. The mean AF value for copper indicated about 70 folds above unity while that of chromium hexavalent revealed more than 20 folds level of enrichment. This is an indication of heavy metal contamination. The high AF values in the rainy season are an indication of anthropogenic inputs resulting from the dissolution of waste materials by precipitation and mobilized through recharged water into the groundwater. The mean value of the index of geoaccumulation $\left(I_{\text {geo }}\right)$ for copper and chromium hexavalent revealed higher values in the rainy season. As mentioned earlier, Mueller (1979) classified the index of geaccumulation into; an index of geaccumulation of $<0$ is practically uncontaminated; $0-1$ is uncontaminated to slightly contaminated; $1-2$ 
Table 5 Summary of indices used for the evaluation pof contamination of heavy metals in the study area

\begin{tabular}{|c|c|c|c|c|c|c|c|}
\hline \multirow[t]{3}{*}{ Heavy metals } & \multicolumn{2}{|c|}{ Average metal values } & \multicolumn{4}{|c|}{ Indices } & \multirow{3}{*}{$\begin{array}{r}\text { Background } \\
\text { value } \\
\text { s }\end{array}$} \\
\hline & \multirow[t]{2}{*}{$\begin{array}{l}\text { Dry } \\
\text { season }\end{array}$} & \multirow[t]{2}{*}{$\begin{array}{l}\text { Rainy } \\
\text { season }\end{array}$} & \multicolumn{2}{|c|}{$\begin{array}{c}\text { Average AF } \\
\text { values }\end{array}$} & \multicolumn{2}{|c|}{ Average $\mathbf{I}_{\text {geo }}$} & \\
\hline & & & $\begin{array}{l}\text { Dry } \\
\text { season }\end{array}$ & $\begin{array}{l}\text { Rainy } \\
\text { season }\end{array}$ & $\begin{array}{l}\text { Dry } \\
\text { season }\end{array}$ & Rainy season & \\
\hline $\begin{array}{l}\text { Chromium } \\
\text { hexavalen } \\
\mathrm{t}(\mathrm{mg} / \mathrm{l})\end{array}$ & 0.02 & 0.20 & 1.8 & 20.1 & -4.7 & -4.6 & 0.01 \\
\hline Copper(mg/l) & 0.43 & 0.69 & 35.0 & 70.0 & -2.3 & -1.6 & 0.01 \\
\hline
\end{tabular}

moderately contaminated; 2-3 moderately to highly contaminated; 3-4 highly contaminated and >5 very highly strongly contaminated. From the above criteria, the mean values of $I_{\text {geo }}$ for chromium hexavalent indicated absence of contamination while copper indicated slight contamination. The heavy metal enrichment in the rainy season is from the dissolution of waste materials. Chromate and cuprite which are the sources of chromium and copper may be unlikely in the Bima sandstone. Consequently, the sources of these metals could be anthropogenic. The correlation between the heavy metals, AF and index of geoaccumulation indicate a strong positive correlation. The correlation ranged from 0.43 to 0.99 for copper and ranged from 0.89 to 1.00 for chromium hexavalent (Table 6). This from buildings and chromium-plated plastics. strong positive correlation is an indication that anthropogenic input is the source of the heavy metals. The positive correlation between AF and $I_{\text {geo }}$ in the dry season as it relates to copper is an indication that the indices are controlled by anthropogenic input. Also, the perfect correlation between $\mathrm{AF}$ and $\mathrm{I}_{\text {geo }}$ in both the dry and rainy season is an indication that the indices are solely influenced by anthropogenic input. Sources of these metals as indicated earlier include water pipes, smelting works, waste from mechanics workshop, metallurgical works, electrical machineries, electronics, car scraps, household solid wastes, pigments resulting from the numerous small-scale industries involve in the dyeing of clothes, inks from computer cart ridges, dissolution of paints.

Table 6 Correlation of heavy metals with the indices used in the evaluation of heavy metal contamination in the study area

\begin{tabular}{|l|l|l|}
\hline $\begin{array}{l}\text { Heavy metals } \\
\text { (mg/l) }\end{array}$ & $\begin{array}{l}\text { Correlating } \\
\text { parameters }\end{array}$ & $\begin{array}{l}\text { Correlation } \\
\text { coefficients }\end{array}$ \\
\hline \multirow{4}{*}{ Copper } & $\mathrm{Cu}$ (rainy season and $\mathrm{AF}$ (rainy season) & 0.99 \\
\cline { 2 - 3 } & $\mathrm{Cu}$ (dry season) and $\mathrm{AF}$ (dry season) & 0.99 \\
\cline { 2 - 3 } & $\mathrm{AF}$ (rainy season) and $\mathrm{I}_{\text {geo }}$ (rainy season) & 0.75 \\
\cline { 2 - 3 } & $\mathrm{Cu}$ (rainy season) and $\mathrm{I}_{\text {geo }}$ (rainy season) & 0.74 \\
\cline { 2 - 3 } & $\mathrm{AF}$ (dry season) and $\mathrm{I}_{\text {geo }}$ (dry season) & 0.43 \\
\hline \multirow{4}{*}{$\begin{array}{l}\text { Chromium } \\
\text { hexavalent }\end{array}$} & $\mathrm{Cr}$ (dry season) and $\mathrm{AF}$ (dry season) & 1.00 \\
\cline { 2 - 3 } & $\mathrm{AF}$ (rainy season) and $\mathrm{Cr}^{+6}$ (rainy season) & 1.00 \\
\cline { 2 - 3 } & $\mathrm{Cr}^{+6}$ (dry season) and $\mathrm{I}_{\text {geo }}$ (dry season) & 0.92 \\
\cline { 2 - 3 } & $\mathrm{I}_{\text {geo }}$ (rainy season) and $\mathrm{Cr}^{+6}$ (rainy season) & 0.89 \\
\cline { 2 - 3 } & $\mathrm{AF}$ (rainy season) and $\mathrm{I}_{\text {geo }}$ (rainy season) & 0.89 \\
\hline
\end{tabular}

$\mathrm{AF}=$ anthropogenic factor

$\mathrm{I}_{\text {geo }}=$ index of geoaccumulation

\section{CONCLUSION}

The consequences of indiscriminate waste disposal practice are responsible for the degradation of groundwater quality in many urban centers including the study area. This study has demonstrated that indiscriminate waste disposal practice is responsible for the heavy metal contamination in the study area. The study revealed that heavy metal contamination occurred in the rainy season as revealed by the mean concentration values of chromium hexavalent and copper which is in the order of $\mathrm{Cr}^{+6}<\mathrm{Cu}$. The indication of heavy metal contamination is also confirmed by the higher mean values of the metals which ranged higher than the back ground values. This is a clear indication of anthropogenic inputs related to household solid wastes, water pipes, smelting works, wastes from mechanic workshop, metallurgical works, electronics, car scraps, small-scale textile activities, computer inks, dissolution of paints from buildings and chromium-plated plastics. 
Indication of anthropogenic contamination is also revealed by higher AF mean values in the rainy season. The AF mean value for copper indicated about 70 folds enrichment over AF value of 1 while chromium hexavalent was enriched by more than 20 folds. The strong positive correlation between the heavy metals, $A F$ and $I_{\text {geo }}$ is an indication that anthropogenic input could be the most likely source of the metals. The positive correlation between nitrate, $\mathrm{Ec}$ and $\mathrm{pH}$ is also an indication of a common anthropogenic source. The mean values of chromium hexavalent, nitrate and coliform bacteria ranged above the recommended limits of WHO in both the dry season and rainy season periods. It can be concluded from this study that heavy metal contamination occurred in the rainy season period in the order of abundance as $\mathrm{Cr}^{+6}<\mathrm{Cu}$. The groundwater quality in the area is unfit for human consumption prior to treatment due to contamination by chromium hexavalent, nitrate and coliform bacteria. This study recommends the following steps towards the protection and conservation of groundwater quality;

a) People should be discouraged from consuming contaminated water, and periodic water analysis should be carried out.

b) All refuse dumpsites should be closed and legislation should be enacted regarding illegal dumps. Refuse collection centers should be erected at designated areas.

c) Land fill should be constructed over the basement complex rocks along the Dumne junction some $50 \mathrm{Km}$ from Yola.

d) Boreholes in the alluvium aquifers should be drilled between the total depths of $60-80$ metres rather than the present practice of 40 metres and below.

e) All boreholes drilled along the edges of the drainage networks be sealed or chlorinated at six months intervals.

\section{REFERENCES}

Abbasi, S.A. and R. Soni., 1984. Teratogenic effects of chromium (VI) in the environment as evidenced by the impact of lavae of Amphibian Rand tigrina: Implications in the Environmental Management of Chromium. Int. J. Environmental Studies, 23: 131-137.

Adekeye, J.I.D. and Ishaku, J.M., 2004.

Groundwater contamination in shallow aquifers of Jimeta metropolis, Adamawa State, N.E. Nigeria. Zuma Journal of Pure and Applied Sciences (6), pp150- 159.

Alloy, B.J. 1990. Processes and the behavior of metals. Pp7-28 In Alloway (ed.). Heavy metals in soils. John Wiley \& Sons. New York.

Barcelon, M.J., Gibb, J.P., Helfrich, J.A. and Garske, E.E., 1985. Practical guide for groundwater sampling. ISWS contract report 374 , Illinois, $94 p$.
Bonatti, S., Meini, M. and Abbondandolo, A., 1976. Genetic effects of potassium chromate in Schizosaccharomyces pombe. Murat. Res., 38: 147-149.

Brilly, M., Brigita, J., and Damjana, D., 2003.

Chromium contamination of the Ljubljansko Polje aquifer. RMZ-Materials and Geoenvironment, Vol 50, N0. 1, pp 71-74.

Carl, D.P., and Robert, W.P., 1994. Natural Attenuation of Hexavalent chromium in groundwater and soils. EPA Groundwater Issue, $12 \mathrm{p}$.

Centre FOR Disease Control., 2003. Drinking water. Copper and drinking water from private wells. http://www.nsf.org/

Chilton, J., 1992. Groundwater. Water quality Assessment- A guide to use of biota; sediments and water in environmental monitoring, $2^{\text {nd }}$ ed. UNESCO/WHO/UNEP.

Christeinsen, T.H., 1992. Attenuation of leachate pollutants in groundwater. In: Landfilling of wastes: leachate (Christensen, T.H., R. Cossu, R. Stegmann, Editors), London, Elsevier Applied Science. Pp470-475.

Davis, S.N. and R.I.M. De Wiest., 1966. Hydrogeology. John Wiley \& Sons, New York, $463 p$.

Eduvie, M.O., 2000. Groundwater assessment and development in the Bima sandstone: Case study of Yola-Jimeta Area. WATER RESOURCESJournal of Nigerian Association of hydrogeologists (NAH), vol. li, pp31-38.

Freeze, R.A., and Cherry, J.A., 1979. Groundwater: Prentice Hall, Inc. Englewood Cliffs, New Jessey. 603p.

Gibbs, R.J., 1977.Transport of transition metals in the Amazon and Yiukon Rivers. Geological society of American Bulletin, 88: 829-843.

Hem, J.D., 1984. Study and Interpretation of the Chemical Characteristics of Natural water. U.S Geological Survey water-supply paper $224.3^{\text {rd }}$ ed., $263 p$.

Ishaku. J.M., 1995. The Hydrogeology of Yola area and Environs in the Upper Benue River Basin. MSc Thesis (unpublished). Department of Geology, University of Nigeria, Nsukka.

Ishaku, J.M., 2007. Waste disposal and groundwater quality in Jimeta- Yola area, Adamawa State,

SEASONAL VARIATION IN CHROMIUM HEXAVALENT AND COPP

Ishaku, J.M., and Ezeigbo, H.I., 2000. Water quality of Yola area, northern Nigeria. WATER RESOURCES. Journal of the Nigerian 
Association of Hydrogeologists (NAH), vol. 1, pp39-48.

Jenne, E.A., 1968. Controls on Mn, Fe, Co, Ni, Cu, and $\mathrm{Zn}$ concentrations in soils and water: The significant role of hydrous $\mathrm{Mn}$ and $\mathrm{Fe}$ oxides. Adv. Chem. Ser. 73:337.

Mancuso, T.F., 1951. Occupational cancer and Other Health Hazards in a Chrome plant. A medical Appraissal li. Clinical and Toxicological Aspects. Ind. Med. Surg. 20:393-407.

Mancuso, T.F., and W.C. HEUPER., 1951. Occupational Cancer and Other Health Hazards in a Chrome plant. A medical Appraissal. Lung Cancers in Chrome workers. Ind. Med. Surg. 20;358-363.

Minnesota Pollution Control Agency. 1999.

Copper, Chromium, Nickel and Zinc in Minnesta's groundwater.

http//www.pca.state.mn.us/water/groundwater/g wmap/index.html.

McLean, J.E., and B.E. Bledsoe. 1992. Behavior of metals in soils. Tech. Res. Doc. EPA/54OS92/018. Environs. Res. And Development, USEPA. Ada. OK.

Muller, G., 1979. SchWermettale in den sedimen des Rheins-veraenderungen seit. 1971. Umschau; 79:778-783.

NPC, 2006. Population of the Federal Republic of Nigeria. Adamawa State. Preliminary report.

Ntekim, E.E., and Bello, H., 2001.Evaluation of heavy metal contents of soils and well water around Jimeta bridge, Yola, northeastern Nigeria. J. Min. Geol. Vol. 37(2), pp103-111.

Offodile, M.E., 1989. A review of the Geology of Cretaceous of the Benue Trough. In Geology of Nigeria (Edited by Kogbe, 1989) Lagos, Nigeria: Elizabeth publishing House, pp365-376.

Offodile, M.E., 2002. Groundwater supply and development in Nigeria. Mecon Geology and Eng. Services, 453p.

One, B.L., 1988. Genetic Approaches in the study of Chromium. Toxicity and Resistance in Yeast and Bacteria. IN: Chromium in the Natural and Human Environments, vol. 20 (J.O. Nriagu and E. Nieboer, editors). John Wiley \& Sons, New York: 351-368.

Paschin, Y.V., V.I. Kozachenko, and L.E. Sal'nikova, 1983. Differential mutagenic Response at the HGPRT Locust in V-79 and CHO cells after Treatment with Chromate. Mutat. Res. 122: 361-365.
Patrick, O.E. Christopher, N.A., and Gabriel, E.O., 2002. The quality of groundwater in Benin city: A baseline study on inorganic chemicals and microbial contaminants of health importance in boreholes and open wells. Tropical journal of pharmaceutical Research, vol. 1, N0.2, pp75-82.

Salomons, W., Foestner, U., 1984. Metals in Hdrocycle. Springer-Verlag, Berlin, Heidelberg. SHINYA, C., and HIROYUKA, M., 2005. Quatitative analysis of hexavalent chromium in plastics by supersonic wave Extraction. Fujikura Giho (Japanese language) vol., N0. 109, pp5559.

Smith, W.E. and Ailean, M., 1975. Minamata: The poisoning of a city: New Engineer, v.4, pp36.

Sonon, L.D. Kissel, P. Vendrell, and R. Hitchcock, 2006. Copper levels in drinking water from private house hold wells in major provinces of Georgia. Proceedings of the 2006 Georgia Water Resources Conference, held at the University of Georgia.

Tanko, J., and Anametemfiok, V., 2001.Optimization and processes of solid waste collection, transportation and disposal in Yola, Adamawa State.Technical report. Department of Civil Engineering, Federal University of Technology, Yola.

Tijani, M.N., Kennji, J., and Yoshinari, H., 2004. Environmental impact of heavy metals distribution in water and sediments of Ogunpa River, Ibadan area, southwestern Nigeria. Journal of Mining Geology, vol. 40 (1), pp73-83.

Tijani, M.N., Onodera, S., and Adeleye, M.A., 2005. Environmental implications of adsorbed and total trace metals concentrations in bottomsediments of an urban drainage network in a developing country. RMZ- Materials and Geoenvironment, vol. 52, N0. 1, 127-130.

US Patent, 2005. In-situ process for detoxifying hexavalent chromium in soil and groundwater. US patent, 6955501, 29p.

USEPA, 1975. Quality criteria for Water Federal Register, V.40, N0, 248, pp59566-59588.

Van Weerelt, M., W.C. Pfeiffer, and M. Fiszman, 1984. Uptake and Release of ${ }^{51} \mathrm{Cr}(\mathrm{VI})$ and ${ }^{51} \mathrm{Cr}$ (III) by Bamacles (Balanus sp). Mar. Environ. Res. 11:201-211.

\section{4}

Water House, J.A.H., 1975. Cancer among Chromium platers. Br. J. Cancer, 32:262.

WHO, 1984. Guidelines for drinking water quality, vol.1, 
Recommendations. World Health Organization, Geneva. 130p.

WHO, 1993. Guidelines for drinking water quality $2^{\text {nd }}$

Edition. World Health Organization, Geneva.

Yassi, A., and E. Nieboer, 1988. Carcinogenity of Chromium compounds. IN: Chromium in the Natural and Human Environments (J.O. Nriagu and E. Nieboer editors): 443-496.

Yenika, M.E., Uma, J.O., and Obiefuna, G.I., 2003. A case study of shallow aquifer in Jimeta-Yola metropolis, northeastern Nigeria. WATER

RESOURCES. Journal of the Nigerian Association of Hydrogeologists (NAH), vol. 14, pp84-91. 